DOI : https://doi.org/10.24123/jbt.v5i2.4531

\title{
DAMPAK INSENTIF PPH PASAL 21 SAAT PANDEMI COVID19 TERHADAP TAKE HOME PAY DAN PELAPORAN SPT TAHUNAN
}

\author{
Bayu Sarjono \\ Politeknik Ubaya; Surabaya, Indonesia \\ Email : bayu.sarjono@staff.ubaya.ac.id
}

\begin{abstract}
The purpose of this study is to determine the impact of incentives Income Tax Article 21 for the withholding and reporting of the Annual income Tax a Permanent Employee. This type of research is descriptive research with case study approach of research about the status of subject of the study with respect to a specific phase or typical of the whole personality. The data were obtained from dokumetansi i.e. data earnings a permanent employee, the calculation of Income Tax Article 21, and form 1721 A1. The Unit of analysis in this research was the individual as a lecturer at the University of $Y$ included in the KLU taxpayers affected by the pandemic Covid19.Income tax Article 21 for the Period of January to March to dependents of employees, thereby reducing the magnitude of the Take Home Pay received. From April to December, employees with certain criteria were given an incentive of income Tax Article 21 by the Government and income Tax withheld by the employer was given simultaneously with the monthly income. With the tax incentives it can increase the Take Home Pay received. Article 21 income tax Borne by the Government received by the employee from the employer is not taken into account as income subject to taxation. Therefore, it must be reported in the tax return (SPT) Annual Personal Income Tax. But in this case the employer does not provide data to the employee about the amount of income Tax Article 21 Borne by the Government.
\end{abstract}

Keywords : pandemic covid19, tax incentives, Income Tax Article 21, the Annual Personal Income Tax

\section{Pendahuluan}

Sumber penerimaan negara menurut APBN sesuai Undang-Undang terdiri dari penerimaan dalam negeri dan hibah. Penerimaan dalam negeri terdiri dari penerimaan dari sektor pajak dan bukan pajak. Pada penerimaan sektor pajak terbagi lagi menjadi penerimaan pajak dalam negeri dan penerimaan pajak atas perdagangan internasional. Penerimaan bukan pajak terdiri dari laba Badan Usaha Milik Negara (BUMN), penerimaan sumber daya alam, dan penerimaan negara bukan pajak (PNBP) lainnya. Penerimaan perpajakan selalu menempati posisi teratas dalam menyumbang pendapatan negara. 
Pajak Penghasilan (PPh) Pasal 21 atau karyawan diproyeksikan akan menjadi penggerak penerimaan pajak di tahun ini. Proyeksi itu muncul mengingat PPh Pasal 21 yang terus bertumbuh selama beberapa tahun terakhir. Berdasarkan data Anggaran Pendapatan dan Belanja Negara (APBN) 2019, realisasi penerimaan PPh Pasal 21 sepanjang tahun lalu sebesar Rp 148,63 triliun, tumbuh 10,2\% dari tahun sebelumnya. Sementara realisasi di 2018 senilai Rp 134,9 triliun, melonjak 14,5\%. Kemudian, pencapaian di 2017 sebanyak Rp 117,8 triliun atau naik 7,4\%. Kementerian Keuangan menargetkan, penerimaan PPh dari karyawan di 2020 mencapai Rp 163,4 triliun. Angka ini tumbuh 9,07\% dibanding realisasi 2019. Kinerja penerimaan pajak penghasilan dari karyawan yang dibayarkan korporasi ini baik, setidaknya dalam tiga tahun terakhir.

Saat ini seluruh belahan dunia sedang menghadapi pandemi Covid19, yang sudah ditetapkan sebagai bencana nasional di Indonesia sehingga perlu upaya pengaturan dalam rangka mendukung penanggulangan dampak Covid19. Diperlukan penyelamatan, diperlukan stimulus ekonomi, yang menyentuh sektor-sektor yang paling terdampak. Sektor riil ini menyerap banyak tenaga kerja dan kita harapkan mereka mampu bertahan dan tidak melakukan PHK (Pemutusan Hubungan Kerja). Pandemi Covid19 telah berdampak terhadap perlambatan pertumbuhan ekonomi nasional, penurunan penerimaan negara, dan peningkatan belanja negara dan pembiayaan. Pemerintah berusaha melakukan penyelamatan kesehatan dan perekonomian nasional, salah satunya dengan memberikan kebijakan berupa insentif pajak. Permasalahan yang saat ini berkaitan dengan dampak pandemi Covid19 ini telah memperlambat ekonomi dunia secara masif dan signifikan termasuk perekonomian Indonesia. Pandemi Covid19 di Indonesia merupakan bagian dari pandemi penyakit corona virus 2019 yang sedang berlangsung di seluruh dunia. Kasus positif Covid19 di Indonesia pertama kali dideteksi pada tanggal 2 Maret 2020, ketika dua orang terkonfirmasi tertular dari seorang warga negara Jepang. Covid19 sendiri sudah dinyatakan sebagai bencana non alam yang mempengaruhi stabilitas ekonomi dan juga penerimaan negara oleh pemerintah.

Untuk mengantisipasi beberapa dampak Covid19, Pemerintah telah dan terus mengambil kebijakan dan langkah-langkah untuk mengantisipasinya dengan tujuan untuk menjaga stabilitas pertumbuhan ekonomi, daya beli masyarakat dan produktivitas sektor tertentu sehubungan dampak wabah Covid 19 ini, dan untuk mendukung penanggulangan dampak Covid19. Pemerintah meluncurkan berbagai program relaksasi pajak sebagai upaya meminimalisir dampak ekonomi masyarakat akibat pandemi Covid19. Pemerintah memberikan insentif pajak kepada Wajib Pajak, melalui Menteri Keuangan mengeluarkan Peraturan Menteri Keuangan tentang insentif pajak untuk Wajib Pajak terdampak Pandemi Covid19 salah satunya adalah insentif Pajak Penghasilan Pasal 21 Ditanggung Pemerintah. Pemberian insentif ini sebagai respon dari pemerintah atas menurunnya produktivitas para pelaku usaha.

Berbeda dari pembahasan penelitian oleh penulis lain, tujuan dalam penelitian ini adalah untuk mengetahui a) pemotongan Pajak Penghasilan Pasal 21 sebelum ada insentif pajak Ditanggung Pemerintah, b) pemotongan Pajak Penghasilan Pasal 21 sebelum ada insentif pajak ditanggung Pemerintah saat pandemi Covid19, dan c) dampak insentif pajak ditanggung Pemerintah pada pelaporan SPT Tahunan untuk Pegawai Tetap.

\section{Kerangka Teori}

Pengertian pajak menurut Rochmat Soemitro, dalam Mardiasmo(2016:1) mengungkapkan bahwa Pajak ialah pemberian uang dari masyarakat (iuran) untuk negara yang telah diatur dalam undang-undang yang bisa dilakukan paksaan dan tidak 
mendapatkan jasa timbal kontraprestasi secara langsung yang dipergunakan untuk pembayaran pada umumnya. Menurut Waluyo (2011:12), pajak mempunyai beberapa fungsi, yaitu:

a. Fungsi Anggaran (Budgetair) : Fungsi budgetair disebut juga sebagai fungsi utama pajak atau fungsi fiskal (fiscal function), yaitu suatu fungsi dimana pajak dipergunakan sebagai alat untuk memasukkan dana secara optimal ke kas negara berdasarkan Undang-undang perpajakan yang berlaku. Fungsi ini disebut fungsi utama karena fungsi inilah yang secara historis pertama kali timbul. Di sini pajak merupakan sumber pembiayaan negara yang terbesar.

b. Sebagai Alat Pengatur (Regulerend) : Fungsi ini mempunyai pengertian yangberarti bahwa pajak dapat disajikan sebagai instrumen untuk mencapai tujuan tertentu. Sebagai contoh, ketika pemerintah berkeinginan untuk melindungi kepentingan petani dalam negeri, pemerintah dapat menetapkan pajak tambahan, seperti pajak impor atau bea masuk atas kegiatan impor komoditas tertentu.

c. Sebagai Alat Penjaga Stabilitas : Pemerintah dapat menggunakan sarana perpajakan untuk stabilitas ekonomi. Sebagian barang-barang impor dikenakan pajak agar produksi dalam negeri dapat bersaing. Untuk menjaga stabilitas nilai tukar rupiah dan menjaga agar defisit perdagangan tidak semakin melebar, pemerintah dapat menetapkan kebijakan penggunaan $\mathrm{PPnBm}$ terhadap impor produk tertentu yang bersifat mewah.

d. Fungsi Retribusi Pendapatan : Pemerintah membutuhkan dana untuk membiayai pembangunan infrastruktur, seperti jalan raya dan jembatan. Kebutuhan akan dana itu dapat terpenuhi melalui pajak yang hanya dibebankan kepada mereka yang mampu membayar pajak. Namun demikian, infrastruktur yang dibangun tadi, dapat juga dimanfaatkan oleh mereka yang tidak mampu membayar pajak.

\section{Pajak Penghasilan Pasal 21}

Pajak Penghasilan sehubungan dengan pekerjaan, jasa, dan kegiatan yang dilakukan oleh Wajib Pajak orang pribadi Subjek Pajak dalam negeri, yang selanjutnya disebut $\mathrm{PPh}$ Pasal 21, adalah pajak atas penghasilan berupa gaji, upah, honorarium, tunjangan, dan pembayaran lain dengan nama dan dalam bentuk apapun sehubungan dengan pekerjaan atau jabatan, jasa, dan kegiatan yang dilakukan oleh orang pribadi Subjek Pajak dalam negeri, sebagaimana dimaksud dalam Pasal 21 Undang-Undang Pajak Penghasilan.

Pemotong PPh Pasal 21 dan/atau PPh Pasal 26, meliputi:

a. pemberi kerja yang terdiri dari:

1) orang pribadi;

2) badan; atau

3) cabang, perwakilan, atau unit, dalam hal yang melakukan sebagian atau seluruh administrasi yang terkait dengan pembayaran gaji, upah, honorarium, tunjangan, dan pembayaran lain adalah cabang, perwakilan, atau unit tersebut.

b. bendahara atau pemegang kas pemerintah, termasuk bendahara atau pemegang kas pada Pemerintah Pusat termasuk institusi TNI/POLRI, Pemerintah Daerah, instansi atau lembaga pemerintah, lembaga-lembaga negara lainnya, dan Kedutaan Besar Republik Indonesia di luar negeri, yang membayarkan gaji, upah, honorarium, tunjangan, dan pembayaran lain dengan nama dan dalam bentuk apapun sehubungan dengan pekerjaan atau jabatan, jasa, dan kegiatan;

c. dana pensiun, badan penyelenggara jaminan sosial tenaga kerja, dan badanbadan lain yang membayar uang pensiun secara berkala dan tunjangan hari tua atau jaminan hari tua; 
d. orang pribadi yang melakukan kegiatan usaha atau pekerjaan bebas serta badan yang membayar:

1. honorarium, komisi, fee, atau pembayaran lain sebagai imbalan sehubungan dengan jasa yang dilakukan oleh orang pribadi dengan status Subjek Pajak dalam negeri, termasuk jasa tenaga ahli yang melakukan pekerjaan bebas dan bertindak untuk dan atas namanya sendiri, bukan untuk dan atas nama persekutuannya;

2. honorarium, komisi, fee, atau pembayaran lain sebagai imbalan sehubungan dengan jasa yang dilakukan oleh orang pribadi dengan status Subjek Pajak luar negeri;

3. honorarium, komisi, fee, atau imbalan lain kepada peserta pendidikan dan pelatihan, serta pegawai magang;

e. penyelenggara kegiatan, termasuk badan pemerintah, organisasi yang bersifat nasional dan internasional, perkumpulan, orang pribadi serta lembaga lainnya yang menyelenggarakan kegiatan, yang membayar honorarium, hadiah, atau penghargaan dalam bentuk apapun kepada Wajib Pajak orang pribadi berkenaan dengan suatu kegiatan.

Penghasilan yang dipotong PPh Pasal 21 dan/atau PPh Pasal 26

a. penghasilan yang diterima atau diperoleh Pegawai Tetap, baik berupa Penghasilan yang Bersifat Teratur maupun Tidak Teratur;

b. penghasilan yang diterima atau diperoleh penerima pensiun secara teratur berupa uang pensiun atau penghasilan sejenisnya;

c. penghasilan berupa uang pesangon, uang manfaat pensiun, tunjangan hari tua, atau jaminan hari tua yang dibayarkan sekaligus, yang pembayarannya melewati jangka waktu 2 (dua) tahun sejak pegawai berhenti bekerja;

d. penghasilan Pegawai Tidak Tetap atau Tenaga Kerja Lepas, berupa upah harian, upah mingguan, upah satuan, upah borongan atau upah yang dibayarkan secara bulanan

e. imbalan kepada Bukan Pegawai, antara lain berupa honorarium, komisi, fee, dan imbalan sejenisnya dengan nama dan dalam bentuk apapun sebagai imbalan sehubungan jasa yang dilakukan;

f. imbalan kepada peserta kegiatan, antara lain berupa uang saku, uang representasi, uang rapat, honorarium, hadiah atau penghargaan dengan nama dan dalam bentuk apapun, dan imbalan sejenis dengan nama apapun;

g. penghasilan berupa honorarium atau imbalan yang bersifat tidak teratur yang diterima atau diperoleh anggota dewan komisaris atau dewan pengawas yang tidak merangkap sebagai Pegawai Tetap pada perusahaan yang sama;

h. penghasilan berupa jasa produksi, tantiem, gratifikasi, bonus atau imbalan lain yang bersifat tidak teratur yang diterima atau diperoleh mantan pegawai;

i. penghasilan berupa penarikan dana pensiun oleh peserta program pensiun yang masih berstatus sebagai pegawai, dari dana pensiun yang pendiriannya telah disahkan oleh Menteri Keuangan.

\section{Insentif Pajak Penghasilan Pasal 21 Ditanggung Pemerintah (DTP)}

Peraturan Menteri Keuangan (PMK) Peraturan Menteri Keuangan Nomor 110/PMK.03/2020 tentang Perubahan atas Peraturan Menteri Keuangan Nomor 86/PMK.03/2020 tentang Insentif Pajak untuk Wajib Pajak Terdampak Pandemi Corona Virus Disease 2019 memperpanjang jangka waktu pemberian insentif Pajak Penghasilan Pasal 21 Ditanggung Pemerintah (DTP) hingga Desember 2020. Daftar jenis usaha yang mendapatkan insentif PPh 21 Ditanggung Pemerintah juga bertambah 
Kriteria Perusahaan Bisa Mengajukan Insentif PPh 21 Ditanggung Pemerintah

Perusahaan yang bisa mengajukan insentif Pajak Penghasilan (PPh) Pasal 21 Ditanggung Pemerintah untuk karyawan atau pegawainya sesuai Pasal 2 ayat (3) PMK No. 86/2020 adalah :

a. Perusahaan memiliki kode Klasifikasi Lapangan Usaha (KLU) penerima insentif PPh 21 DTP

b. Perusahaan telah ditetapkan sebagai Perusahaan KITE (Kemudahaan Impor Tujuan Ekspor)

c. Perusahaan telah mendapatkan izin Penyelenggara Kawasan Berikat, izin Pengusaha Kawasan Berikat (PKB), atau izin Pengusaha Dalam Kawasan Berikat (PDKB)

Pegawai dengan Kriteria Tertentu yang Mendapatkan Fasilitas PPh 21 Ditanggung Pemerintah

a. Menerima atau memperoleh penghasilan dari Pemberi Kerja yang memenuhi syarat sebagai pemberi kerja yang dapat memotong PPh 21 ditanggung pemerintah.

b. Memiliki NPWP

c. Pada Masa Pajak yang bersangkutan menerima atau memperoleh Penghasilan Bruto yang bersifat tetap dan teratur yang disetahunkan tidak lebih dari Rp 200.000.000 (dua ratus juta rupiah).

\section{Surat Pemberitahuan (SPT)}

Pasal 1 angka 11 UU KUP mendefinisikan Surat Pemberitahuan merupakan surat yang oleh Wajib Pajak digunakan untuk melaporkan penghitungan dan/atau pembayaran pajak, objek pajak dan/atau bukan objek pajak, dan/atau harta dan kewajiban sesuai dengan ketentuan peraturan perundang-undangan perpajakan. Fungsi SPT bagi Wajib Pajak PPh antara lain :

a. Sebagai sarana untuk melaporkan dan mempertanggungjawabkan perhitungan jumlah pajak yang sebenarnya terutang;

b. Untuk melaporkan pembayaran atau pelunasan pajak yang telah dilakukan sendiri dan/atau melalui pemotongan atau pemungutan pajak lain dalam satu tahun pajak;

c. Melaporkan penghasilan, harta dan kewajiban, serta pembayaran dari pemotong/pemungut atas pemotongan dan pemungutan Pajak yang telah dilakuka

Jenis SPT dilihat dari periode pelaporan terdiri dari dua jenis, yaitu :

a. SPT Masa

SPT Masa adalah Surat Pemberitahuan untuk suatu Masa Pajak. Jenis pajak yang harus dilaporkan setiap bulan melalui SPT Masa terdiri dari : PPh Pasal 21, PPh Pasal 22, PPh Pasal 23, PPh Pasal 25, PPh Pasal 26, PPh Pasal 4 Ayat 2, PPh Pasal 15, PPN \& PPn BM, Pemungut PPN.

b. SPT Tahunan

SPT Tahunan adlah Surat Pemberitahuan untuk suatu Tahun Pajak atau Bagian Tahun Pajak. SPT Tahunan terbagi menjadi dua kategori, yaitu SPT Tahunan PPh Orang Pribadi dan SPT Tahunan PPh Badan. SPT Tahunan PPh Orang Pribadi terbagi dalam tiga jenis yang terdiri dari SPT Tahunan 1770, SPT 1770 S, dan SPT 1770 SS. Yang menjadi perbedaan diantara ketiga jenis SPT Tahunan ini terletak pada status kepegawaian seseorang, sumber lain, serta besaran penghasilan bruto Wajib Pajak setiap tahun. 


\section{Metode Penelitian}

\section{Jenis Penelitian}

Penelitian ini merupakan jenis penelitian deskiptif dengan pendekatan studi kasus yaitu penelitian tentang status subjek penelitian yang berkenaan dengan suatu fase spesifik atau khas dari keseluruhan personalitas. Subjek penelitian dapat saja individu, kelompok, lembaga, maupun masyarakat. Tujuan studi kasus adalah untuk memberikan gambaran secara mendetail tentang latar belakang, sifat-sifat serta karakter-karakter yang khas dari kasus, ataupun status dari individu, yang kemudian dari sifat-sifat khas di atas akan dijadikan suatu hal yang bersifat umum dalam Nazir (2005:57)

\section{Unit analisis}

Yang menjadi unit analisis dalam penelitian ini adalah individu sebagai tenaga pendidik di Universitas Y yang termasuk dalam KLU Wajib Pajak yang terdampak pandemi Covid19. Fokus penelitian yang dilakukan adalah data pemotongan Pajak Penghasilan Pasal 21 pegawai tetap selama tahun 2020 untuk melihat dampak insentif pajak yang diberikan Pemerintah terhadap Take Home Pay dan Pelaporan SPT Tahunan Pajak Penghasilan Orang Pribadi

\section{Sumber Data}

Sumber data dalam penelitian ini diperoleh dari dokumentasi yang terkait dengan penghasilan yang diterima/diperoleh Pegawai Tetap meliputi gaji pokok, tunjangan, honorarium, THR, serta bonus yang diberikan kepada para karyawan perusahaan, bukti pemotongan PPh Pasal 21 berupa formulir 1721 A1.

\section{Teknik Pengumpulan data}

Data yang digunakan dalam penelitian ini diperoleh dengan metode dokumentasi. Peneliti menggunakan data penghasilan Pegawai Tetap, Pajak Penghasilan Pasal 21 yang dipotong dan bukti pemotongan Pajak Penghasilan Pasal 21 berupa formulir 1721 A1 yang dibuat oleh pemberi kerja untuk tahun pajak 2020.

\section{Analisis Data}

Penelitian ini menggunakan metode analisis deskriptif. Proses analisis yang dilakukan:

a. Tahap pertama, mengidentifikasi penghasilan pegawai tetap baik yang bersifat teratur dan tidak teratur.

b. Tahap kedua, menganalisis perhitungan dan pemotongan PPh Pasal 21 yang dilakukan pemberi kerja sebelum ada insentif pajak Ditanggung Pemerintah yaitu bulan Januari - Maret 2020, dan perhitungan dan pemotongan PPh 21 untuk bulan April - Desember 2020 setelah ada insentif pajak Ditanggung Pemerintah.

c. Tahap ketiga, menganalisa dampak insentif PPh Pasal 21 Ditanggung Pemerintah terhadap Take Home Pay yang diterima pegawai.

d. Tahap keempat, menganalisa dampak insentif pajak Ditanggung Pemerintah pada pelaporan SPT Tahunan PPh Orang Tahun Pribadi tahun pajak 2020

\section{Hasil dan Pembahasan}

\section{Pemotongan PPh Pasal 21 sebelum ada insentif PPh}

Pada awal Maret 2020, Pemerintah telah mengumumkan dua kasus positif Covid19 masuk di Indonesia, namun pada saat itu belum ada insentif pajak yang diberikan. Pandemi Covid19 yang terjadi memberikan tekanan besar pada kondisi dunia, 
khususnya pada sektor ekonomi dan kesehatan. Pandemi Covid19 merupakan bencana nasional yang mempengaruhi stabilitas ekonomi dan produktivitas masyarakat sebagai pegawai sehingga perlu dilakukan upaya pengaturan dalam rangka mendukung penanggulangan dampak Covid19. Untuk menjaga stabilitas pertumbuhan ekonomi, daya beli masyarakat, dan produktivitas sektor tertentu sehubungan dengan wabah Covid19 maka Pemerintah Indonesia perlu memberikan insentif pajak dalam rangka mendukung penanggulangan dampak virus corona. Maka dari itu terbitlah Peraturan Menteri Keuangan No.23/PMK.03/2020 tentang insentif pajak untuk wajib pajak yang terdampak wabah virus corona, dimana salah satu insentif pajak yang diberikan adalah insentif $\mathrm{PPh}$ Pasal 21 ditanggung Pemerintah untuk 440 Klasifikasi Lapangan Usaha (KLU). Peraturan Menteri ini ditetapkan pada 21 Maret 2020 dan berlaku mulai 1 April 2020, sehingga untuk pemotongan PPh Pasal 21 Masa Maret 2020 belum mendapatkan insentif pajak.

Pemotongan PPh Pasal 21 Masa Januari - Maret 2020 mengikuti ketentuan perpajakan yang berlaku dimana belum ada insentif pajak yang diberikan. Berikut rincian data penghasilan Tuan A sebagai tenaga pendidik pada Universitas Y di Surabaya.

Tabel 4.1 Pemotongan Sebelum ada Insentif PPh Pasal 21

\begin{tabular}{|l|r|r|r|}
\hline \multicolumn{1}{|c|}{ KETERANGAN } & \multicolumn{1}{c|}{ JAN } & \multicolumn{1}{c|}{ FEB } & \multicolumn{1}{c|}{ MAR } \\
\hline Gaji Pokok & 1.027 .448 & 1.027 .448 & 1.027 .448 \\
Tunjangan & 9.501 .372 & 9.501 .372 & 9.501 .372 \\
Honorarium & 2.121 .600 & 1.060 .800 & 2.059 .200 \\
Premi Asuransi dibayar pemberi kerja & 498.203 & 498.203 & 498.203 \\
\cline { 2 - 4 }$\quad$ Jumlah Penghasilan Bruto & 13.148 .623 & 12.087 .823 & 13.086 .223 \\
Pengurang : & & & \\
Biaya Jabatan & 500.000 & 500.000 & 500.000 \\
luran dibayar Pegawai & 412.901 & 412.901 & 416.041 \\
\hline Jumlah Pengurang Penghasilan Bruto & 912.901 & 912.901 & 916.041 \\
Penghasilan Neto Sebulan & 12.235 .722 & 11.174 .922 & 12.170 .182 \\
Penghasilan Neto Setahun & 146.828 .669 & 134.099 .069 & 146.042 .184 \\
PTKP (K/1) & 63.000 .000 & 63.000 .000 & 63.000 .000 \\
\hline PKP Setahun & 83.828 .669 & 71.099 .069 & 83.042 .184 \\
PPh 21 Terutang & & & \\
-5\% & 2.500 .000 & 2.500 .000 & 2.500 .000 \\
-15\% & 5.074 .200 & 3.164 .850 & 4.956 .300 \\
\hline PPh 21 terutang Setahun & 7.574 .200 & 5.664 .850 & 7.456 .300 \\
PPh 21 terutang Sebulan & 631.183 & 472.071 & 621.358 \\
\hline
\end{tabular}

Sumber: Data diolah

Dari tabel di atas, dapat dijelaskan bahwa atas penghasilan yang diterima Pegawai Tetap akan di potong PPh Pasal 21 oleh pemberi kerja untuk bulan Januari sebesar Rp 631.183, Februari sebesar Rp 472.071 dan Maret sebesar Rp 621.358. Besarnya pembayaran utuh (Take Home Pay) diterima Pegawai Tetap sebesar Penghasilan Bruto dikurangi dengan premi asuransi dibayar pemberi kerja, Iuran yang dibayar pegawai dan PPh 21 yang dipotong setiap bulan. 
Tabel 4.2 Take Home Pay sebelum ada Insentif PPh Pasal 21

\begin{tabular}{|l|r|r|r|}
\hline Take Home Pay Pegawai Tetap & \multicolumn{1}{|c|}{ JAN } & \multicolumn{1}{c|}{ FEB } & \multicolumn{1}{c|}{ MAR } \\
\hline Penghasilan Bruto & 13.148 .623 & 12.087 .823 & 13.086 .223 \\
& & & \\
Pengurang : & & & \\
Premi Asuransi dibayar pemberi kerja & $(498.203)$ & $(498.203)$ & $(498.203)$ \\
luran dibayar Pegawai & $(412.901)$ & $(412.901)$ & $(416.041)$ \\
PPh 21 terutang Sebulan & $(631.183)$ & $(472.071)$ & $(621.358)$ \\
\cline { 2 - 4 } THP yang diterima Pegawai Tetap & 11.606 .336 & 10.704 .649 & 11.550 .621 \\
\hline
\end{tabular}

Sumber: Data diolah

Dari tabel di atas dapat dijelaskan bahwa pemberi kerja menerapkan metode gross dalam pemotongan PPh Pasal 21 dimana jumlah PPh Pasal 21 yang terutang menjadi tanggungan pegawai tetap sendiri sehingga benar-benar mengurangi Take Home Pay yang diterima setiap bulannya.

\section{Pemotongan PPh Pasal 21 setelah ada insentif PPh}

Jumlah kasus positif corona di Indonesia yang semakin meningkat menyebabkan banyak sektor yang terkena dampaknya, antara lain sektor pariwisata, manufaktur, UMKM dan sektor informal lainnya. Semakin luasnya sektor yang akan diberikan insentif pajak maka terbitlah Peraturan Menteri Keuangan No. 44/PMK.03/2020 tentang insentif pajak untuk Wajib Pajak terdampak pandemi corona virus disease 2019 dengan jumlah 1.062 Klasifikasi Lapangan Usaha (KLU) yang ditetapkan dan berlaku pada 27 April 2020 menyebutkan bahwa PPh Pasal 21 ditanggung Pemerintah sejak Masa Pajak April 2020 sampai dengan Masa Pajak September 2020. Peraturan Menteri ini mencabut PMK no. 23/PMK.03/2020 karena sudah tidak sesuai dengan perkembangan saat ini dalam rangka penanganan Covid19.

Seiring meningkatnya kasus positif Covid19 di Indonesia yang tersebar di 34 Provinsi sampai pertengahan tahun 2020, membuat Pemerintah Indonesia memperpanjang masa insentif pajak mulai April sampai Desember 2020 dan memperluas sektor usaha yang berhak mendapatkan insentif pajak menjadi 1.189 KLU melalui Peraturan Menteri Keuangan No.86/PMK.03/2020 sehingga ketentuan perpajakan sebelumnya PMK No.44/PMK.03/2020 dicabut dan tidak berlaku. Dengan demikian insentif PPh Pasal 21 untuk pegawai tetap dilanjutkan sampai akhir tahun yang dirubah melalu Peraturan Menteri Keuangan Republik Indonesia Nomor 110/PMK.03/2020.

Berdasarkan peraturan yang berlaku maka pemberi kerja memanfaatkan insentif $\mathrm{PPh}$ Pasal 21 ditanggung Pemerintah. Insentif ini mempengaruhi penghasilan yang diterima oleh setiap pegawai selama 9 (sembilan) bulan selama tahun 2020. Jika sebelumnya pegawai dipotong PPh Pasal 21 atas penghasilan untuk masa Januari - Maret, maka mulai April sampai dengan Desember 2020 pegawai mendapatkan insentif $\mathrm{PPh}$ Pasal 21 ditanggung Pemerintah. Jumlah PPh Pasal 21 yang dipotong oleh pemberi kerja itu diberikan bersamaan dengan penghasilan bulanan yang diterima pegawai. Pajak Penghasilan yang sebelumnya ditanggung oleh penerima penghasilan berubah menjadi Ditanggung Pemerintah (DTP). Berikut ini data perhitungan untuk Pegawai Tetap PPh Pasal 21 Masa April sampai September 2020. 
Tabel 4.3 Pemotongan PPh Pasal 21 setelah memanfaatkan Insentif DTP

\begin{tabular}{|c|c|c|c|c|c|c|c|c|c|}
\hline KETERANGAN & APR & MEI & JUNI & JUL & AGS & SEPT & OKT & NOV & DES \\
\hline Gaji Pokok & 1.027 .448 & 1.027 .448 & 1.027 .448 & 1.027 .448 & 1.027 .448 & 1.047 .998 & 1.047 .998 & 1.150 .015 & 1.150 .015 \\
\hline Tunjangan & 9.501 .372 & 9.501 .372 & 9.501 .372 & 9.501 .372 & 9.501 .372 & 9.502 .400 & 9.502 .400 & 9.507 .500 & 9.507 .500 \\
\hline Honorarium & 2.225 .600 & 3.182 .400 & 2.308 .800 & 2.995 .200 & 1.310 .400 & & 1.092 .000 & 3.369 .600 & 2.534 .100 \\
\hline Premi Asuransi dibayar pemberi kerja & 498.203 & 498.203 & 498.203 & 498.203 & 498.203 & 498.319 & 441.348 & 444.320 & 444.438 \\
\hline $\begin{array}{l}\text { Jumlah Penghasilan Bruto } \\
\text { Pengurang: }\end{array}$ & 13.252 .623 & 14.209.423 & 13.335 .823 & 14.022.223 & 12.337 .423 & 11.048 .718 & 12.083.747 & 14.471.436 & 13.636 .054 \\
\hline Biaya Jabatan & 500.000 & 500.000 & 500.000 & 500.000 & 500.000 & 500.000 & 500.000 & 500.000 & 500.000 \\
\hline Iuran dibayar Pegawai & 416.041 & 416.041 & 416.041 & 416.041 & 416.041 & 418.692 & 418.692 & 431.852 & 431.852 \\
\hline Jumlah Pengurang Penghasilan Bruto & 916.041 & 916.041 & 916.041 & 916.041 & 916.041 & 918.692 & 918.692 & 931.852 & 931.852 \\
\hline Penghasilan Neto Sebulan & 12.336 .582 & 13.293 .382 & 12.419 .782 & 13.106 .182 & 11.421.382 & 10.130 .026 & 11.165 .055 & 13.539 .584 & 12.704 .201 \\
\hline Penghasilan Neto Setahun & 148.038 .984 & 159.520 .584 & 149.037.384 & 157.274 .184 & 137.056 .584 & 121.560 .312 & 133.980 .658 & 162.475 .003 & 166.147 .838 \\
\hline PTKP (K/1) & 63.000 .000 & 63.000 .000 & 63.000 .000 & 63.000 .000 & 63.000 .000 & 63.000 .000 & 63.000 .000 & 63.000 .000 & 63.000 .000 \\
\hline $\begin{array}{l}\text { PKP Setahun } \\
\text { PPh } 21 \text { Terutang }\end{array}$ & 85.038 .984 & 96.520 .584 & 86.037 .384 & 94.274 .184 & 74.056 .584 & 58.560 .312 & 70.980 .658 & 99.475 .003 & 103.147 .838 \\
\hline$-5 \%$ & 2.500 .000 & 2.500 .000 & 2.500 .000 & 2.500 .000 & 2.500 .000 & 2.928 .016 & 2.500 .000 & 2.500 .000 & 2.500 .000 \\
\hline$-15 \%$ & 5.255 .700 & 6.978 .000 & 5.405 .550 & 6.641 .100 & 3.608 .400 & 1.284 .000 & 3.147 .000 & 7.421 .250 & 7.972 .050 \\
\hline PPh 21 terutang Setahun & 7.755 .700 & 9.478 .000 & 7.905 .550 & 9.141 .100 & 6.108 .400 & 4.212 .016 & 5.647 .000 & 9.921 .250 & 10.472 .050 \\
\hline PPh 21 terutang Sebulan & 646.308 & 789.833 & 658.796 & 761.758 & 509.033 & 351.001 & 470.583 & 826.771 & 665.728 \\
\hline
\end{tabular}

Sumber: Data diolah

Dari tabel di atas dapat dijelaskan sesuai dengan ketentuan perpajakan, penghasilan yang diterima pegawai wajib dipotong PPh Pasal 21 oleh pemberi kerja. Namun PPh Pasal 21 yang dipotong tersebur mendapat insentif berupa ditanggung Pemerintah atas penghasilan yang diterima Pegawai dengan kriteria tertentu. Adapun kriteria pegawai dengan kriteria tertentu meliputi menerima atau memperoleh penghasilan dari Pemberi Kerja yang memiliki kode Klasifikasi Lapangan Usaha dalam PMK, memiliki NPWP, dan pada Masa Pajak yang bersangkutan menerima atau memperoleh Penghasilan Bruto yang bersifat tetap dan teratur yang disetahunkan tidak lebih dari Rp200.000.000,00 (dua ratus juta rupiah).

Tabel 4.4 Take Home Pay setelah ada Insentif PPh Pasal 21

\begin{tabular}{|c|c|c|c|c|c|c|c|c|c|}
\hline Take Home Pay Pegawai Tetap & APR & MEI & JUNI & JUL & AGS & SEPT & OKT & NOV & DES \\
\hline Penghasilan Bruto & 13.252.623 & 14.209.423 & 13.335.823 & 14.022 .223 & 12.337 .423 & 11.048 .718 & 12.083 .747 & 14.471 .436 & 13.636 .054 \\
\hline Pengurang : & & & & & & & & & \\
\hline Premi Asuransi dibayar pemberi kerja & (498.203) & (498.203) & (498.203) & (498.203) & (498.203) & (498.319) & (441.348) & (444.320) & $(444.438)$ \\
\hline Iuran dibayar Pegawai & (416.041) & (416.041) & (416.041) & (416.041) & (416.041) & (418.692) & (418.692) & (431.852) & (431.852) \\
\hline PPh 21 terutang Sebulan & (646.308) & (789.833) & (658.796) & (761.758) & $(509.033)$ & (351.001) & (470.583) & (826.771) & $(665.728)$ \\
\hline THP yang diterima Pegawai Tetap & 11.692 .071 & 12.505 .346 & 11.762 .783 & 12.346.221 & 10.914.146 & 9.780 .706 & 10.753 .123 & 12.768 .492 & 12.094 .036 \\
\hline Insentif PPh 21 DTP & 646.308 & 789.833 & 658.796 & 761.758 & 509.033 & 351.001 & 470.583 & 826.771 & 665.728 \\
\hline THP setelah Insentif PPh 21 DTP & 12.338 .379 & 13.295 .179 & 12.421 .579 & 13.107.979 & 11.423 .179 & 10.131 .707 & 11.223.707 & 13.595 .263 & 12.759 .763 \\
\hline
\end{tabular}

Dari tabel 4 dapat dijelaskan PPh Pasal 21 Ditanggung Pemerintah harus dibayarkan secara tunai oleh pemberi kerja pada saat pembayaran penghasilan kepada Pegawai, sehingga Take Home Pay yang diterima pegawai bertambah untuk meningkatkan daya beli masyarakat pada masa pandemi Covid19. Hal ini sejalan dengan Kartiko (2020) yang menyatakan PPh Pasal 21 Ditanggung Pemerintah diharapkan dapat mengurangi dampak pandemi Covid19 yang berakibat pada pemutusan hubungan kerja. PPh Pasal 21 yang dibayarkan secara tunai menjadikan take home pay yang diperoleh pegawai menjadi lebih besar. Hal ini diharapkan dapat meningkatkan konsumsi rumah tangga sehingga dapat roda perekonomian. Hasil penelitian ini juga didukung Hardita (2021) yang menyatakan bahwa PPh 21 yang tidak dipotong diharapkan dapat menjaga daya beli masyarakat.

Selama tahun 2020, pemberi kerja juga memberikan penghasilan tidak teratur berupa Tunjangan Hari Raya dan bonus. Adapun atas penghasilan tersebut tidak mendapatkan insentif PPh Pasal 21 karena merupakan penghasilan yang bersifat tidak teratur. 
Tabel 4.5 PPh Pasal 21 atas Penghasilan Tidak Teratur

\begin{tabular}{|l|r|r|}
\hline \multicolumn{1}{|c|}{ Jenis Penghasilan } & \multicolumn{1}{c|}{ THR } & \multicolumn{1}{c|}{ Bonus } \\
\hline Penghasilan Bruto & 10.528 .820 & 9.922 .015 \\
\hline PPh Pasal 21 & 1.579 .323 & 1.488 .302 \\
\hline Jumlah yang dibayarkan & 8.949 .497 & 8.433 .713 \\
\hline
\end{tabular}

Sumber: Data diolah

Dari tabel di atas dapat dijelaskan bahwa atas penghasilan berupa Tunjangan Hari Raya dipotong PPh Pasal 21 sebesar Rp 1.579.323 dan atas bonus dipotong PPh Pasal 21 sebesar Rp 1.488.302 sehingga mengurangi besarnya jumlah yang dibayarkan kepada pegawai.

Tabel 4.6 Rekapitulasi Penghasilan Januari-Desember

\begin{tabular}{|l|r|}
\hline \multicolumn{1}{|c|}{ KETERANGAN } & \multicolumn{1}{|c|}{ JUMLAH } \\
\hline Gaji Pokok & 12.615 .614 \\
Tunjangan & 114.030 .778 \\
Honorarium & 24.259 .700 \\
Premi Asuransi dibayar pemberi kerja & 5.814 .048 \\
THR & 10.528 .820 \\
Bonus & 9.922 .015 \\
\hline \multicolumn{1}{|c|}{ Jumlah Penghasilan Bruto } & 177.170 .976 \\
Pengurang: & - \\
Biaya Jabatan & 6.000 .000 \\
luran dibayar Pegawai & 5.023 .138 \\
\hline Jumlah Pengurang Penghasilan Bruto & 11.023 .138 \\
& - \\
Penghasilan Neto Setahun & 166.147 .838 \\
PTKP (K/1) & 63.000 .000 \\
PKP Setahun & 103.147 .838 \\
PPh 21 Terutang & - \\
-5\% & 2.500 .000 \\
-15\% & 7.972 .050 \\
\hline PPh Pasal 21 terutang & 10.472 .050 \\
PPh Pasal 21 yang dipotong dan dilunasi & 10.472 .050 \\
\hline
\end{tabular}

Dari tabel di atas dapat dijelaskan bahwa pemotongan PPh Pasal 21 atas seluruh penghasilan baik yang bersifat teratur dan tidak teratur yang diterima pegawai selama tahun 2020 sebagai dasar untuk pembuatan bukti pemotongan form 1721 A1 yang harus diberikan oleh pemberi kerja kepada setiap pegawai. Sedangkan bagi pegawai, form 1721 A1 sebagai bukti untuk mengkreditkan PPh Pasal 21 dalam mengisi SPT Tahunan PPh Orang Pribadi. 
Tabel 4.7 Rincian Pemotongan PPh Pasal 21

\begin{tabular}{|c|c|}
\hline KETERANGAN & JUMLAH \\
\hline PPh Pasal 21 Januari - Maret & 1.724 .612 \\
PPh Pasal 21 April - Desember & 5.679 .812 \\
PPh Pasal 21 THR & 1.579 .323 \\
PPh Pasal 21 Bonus & 1.488 .302 \\
\hline TOTAL & $\mathbf{1 0 . 4 7 2 . 0 5 0}$ \\
\hline
\end{tabular}

Sumber: Data diolah

Dari tabel di atas dapat dijelaskan bahwa PPh Pasal 21 yang dipotong oleh pemberi kerja terdiri dari $\mathrm{PPh}$ Pasal 21 yang menjadi tanggungan pegawai dan $\mathrm{PPh}$ Pasal 21 ditanggung Pemerintah. Adapun PPh Pasal 21 yang menjadi tanggungan pegawai meliputi penghasilan bulan Januari sampai Maret, THR dan Bonus. Sedangkan Masa April sampai Desember 2020 mendapatkan insentif PPh Pasal 21 ditanggung Pemerintah.

\section{Pelaporan SPT Tahunan PPh Orang Pribadi}

Setiap Wajib Pajak Orang Pribadi mempunyai kewajiban untuk melaporkan SPT Tahunan paling lambat 3 bulan setelah akhir tahun pajak dimana jatuh temponya pada 31 Maret 2021. Untuk Wajib Pjak orng pribad yang berstatus sebgai pegawai, maka dasar yang untuk mengisi SPT Tahunan adalah bukti pemotongan berupa form 1721 A1 yang dibuat oleh pemberi kerja. Dikarenakan pada tahun 2020 ada pemberian insentif $\mathrm{PPh}$ Pasal 21 ditanggung Pemerintah,maka maka sesuai dengan ketentuan Pasal 2 ayat 7 PMK No.86/PMK/03/2020 bahwa PPh Pasal 21 ditanggung Pemerintah yang diterima oleh Pegawai dari Pemberi Kerja tidak diperhitungkan sebagai penghasilan yang dikenakan pajak.

Tabel 4.8 Besarnya Insentif PPh Pasal 21 DTP

\begin{tabular}{|l|r|r|}
\hline THP yang diterima Jan - Des 2020 & & 161.541 .552 \\
THP menurut bukti pemotongan 1721 A1 & & \\
Penghasilan Bruto & 177.170 .976 & \\
Dikurangi : & & \\
Premi Asuransi dibayar pemberi kerja & $(5.814 .048)$ & \\
luran dibayar Pegawai & $(5.023 .138)$ & \\
PPh Pasal 21 yang dipotong dan dilunasi & $(10.472 .050)$ & \\
& & $\frac{155.861 .740}{5.679 .812}$ \\
\hline
\end{tabular}

Sumber: Data diolah

Dari tabel di atas dapat dijelaskan bahwa Take Home Pay yang diterima secara langsung oleh pegawai lebih besar daripada Take Home Pay berdasarkan Form 1721 A1. Hal ini dikarenakan adanya insentif $\mathrm{PPh} 21$ Ditanggung Pemerintah sebesar Rp 5.679.812. Dengan adanya kenaikan jumlah Take Home Pay yang berasal dari insentif PPh Pasal 21 Ditanggung Pemerintah, maka harus dilaporkan di dalam SPT Tahunan PPh Orang Pribadi Tahun Pajak 2020 di bagian penghasilan yang tidak termasuk objek pajak. Untuk mengetahui berapa besarnya insentif PPh Pasal 21 Ditanggung Pemerintah yang diterima pegawai sebaiknya pemberi kerja memberikan data kepada pegawai selain formulir 1721 A1 terkait besaran insentif $\mathrm{PPh}$ Pasal 21. Dalam hal ini dikarenakan pemberi kerja tidak memberikan data tersebut kepada pegawai sehingga pegawai tidak dapat mengisi besarnya penghasilan yang tidak termasuk objek pajak di SPT Tahunan Pajak Penghasilan Orang Pribadi. Hal ini didasarkan pada UU KUP yang menyatakan 
bahwa setiap Wajib Pajak harus mengisi Surat Pemberitahuan (SPT) dengan benar, lengkap dan jelas.

\begin{tabular}{|c|c|c|c|c|}
\hline No. & \multicolumn{3}{|l|}{ JENIS PENGHASILAN } & $\begin{array}{l}\text { JUMLAH PENGHASILAN } \\
\text { (Rupiah) }\end{array}$ \\
\hline (1) & (2) & & & (3) \\
\hline 1. & BANTUAN/SUMBANGAN/HIBAH & & & \\
\hline 2. & WARISAN & & & \\
\hline 3. & $\begin{array}{l}\text { BAGIAN LABA ANGGOTA PERSEROAN KOMANDITER TIDAK ATAS SAHAM, } \\
\text { PERSEKUTUAN, PERKUMPULAN, FIRMA, KONGSI }\end{array}$ & & & \\
\hline 4. & KLAIM ASURANSI KESEHATAN, KECELAKAAN, JIWA, DWIGUNA, BEASISWA & & & \\
\hline 5. & BEASISWA & & & \\
\hline 6. & PENGHASILAN LAINNYA YANG TIDAK TERMASUK OBJEK PAJAK & & & 5.679 .812 \\
\hline & JUMLAH BAGIAN B & <AUTO> & JBB & 5.679 .812 \\
\hline
\end{tabular}

Gambar 4.1 Pelaporan Insentif PPh Pasal 21 DTP

\section{Simpulan dan Saran}

Penghasilan yang diterima atau diperoleh pegawai tetap sebagai Wajib Pajak dalam negeri merupakan objek pajak penghasilan pasal 21. Salah satu dampak pandemi covid19 adalah menurunnya daya beli masyarakat. Untuk mengatasi dampak tersebut, Pemerintah mengeluarkan kebijakan berupa pemberian insentif pajak bagi Wajib Pajak yang terdampak covid19. Salah satu insentif yang diberikan adalah PPh Pasal 21 ditanggung Pemerintah yang diberikan kepada pegawai dengan kriteria tertentu. Pegawai dengan kriteria tertentu meliputi menerima/memperoleh penghasilan dari pemberi kerja yang memiliki kode Klasifikasi Lapangan Usaha (KLU) tertentu, memiliki NPWP, dan pada masa pajak yang bersangkutan menerima/memperoleh Penghasilan Bruto yang bersifat tetap dan teratur yang disetahunkan tidak lebih dari 200 juta rupiah. Insentif pajak ini diberikan mulai bulan April sampai Desember 2020. Dengan adanya pemberian insentif PPh Pasal 21 diharapkan dapat meningkatkan daya beli masyarakat.

Mekanisme pemotongan PPh Pasal 21 mengikuti ketentuan PER 16/PJ/2016. Pemberi kerja setelah menghitung dan memotong PPh Pasal 21, selanjutnya PPh Pasal 21 yang dipotong tersebut harus dibayarkan secara tunai oleh pemberi kerja pada saat pembayaran penghasilan kepada Pegawai setiap bulannya. Dengan adanya PPh Pasal 21 ditanggung Pemerintah akan meningkatkan Take Home Pay yang diterima sehingga pegawai bisa menjaga daya beli untuk konsumsi. Insentif PPh Pasal 21 yang yang diterima oleh pegawai tidak diperhitungkan sebagai penghasilan yang dikenakan pajak. Sebagai bukti pemotongan PPh Pasal 21, pemberi kerja wajib memberikan bukti potong berupa form 1721 A1 kepada setiap pegawai tetap. Di samping itu, sebaiknya pemberi kerja juga memberikan data rincian insentif $\mathrm{PPh}$ Pasal 21 ditanggung Pemerintah yang diterima oleh setiap pegawai muai April sampai Desember 2020.Hal ini digunakan untuk pelaporan di SPT Tahunan $\mathrm{PPh}$ Orang Pribadi. Besarnya insentif PPh Pasal 21 ditanggung Pemerintah dilaporkan di form SPT Tahunan bagian penghasilan yang tidak termasuk objek pajak.

Mengingat pandemi covid19 sampai saat ini masih belum berakhir dan pemerintah masih memperpanjang pemberian insentif pajak untuk penanggulangan dampak covid19, maka dapat disarankan bagi penelitian selanjutnya melakukan analisis dampak insentif pajak yang diberikan pemerintah pada sektor lain seperti sektor otomotif dan pariwisata selama masa pandemi sehingga dapat dilihat dampak insentif pajak terhadap kinerja keuangan perusahaan. 


\section{Daftar Pustaka}

Hadita, Rahma Safitri, dkk. 2021. Implementasi Kebijakan PPh 21 Selama Pandemi Covid-19 di Provinsi DKI Jakarta. Jurnal Ilmu Administrasi Publik Dan Bisnis. Volume 1, Nomor 4, Maret 2021.

Hafis, Dwi. 2020. Insentif Pajak Dalam Merespon Dampak Pandemi Covid-19 pada Sektor Pariwisata. Jurnal Pajak dan Keuangan Negara Vol.II, No.1. Hal.124-137

Mardiasmo. 2016. Perpajakan. CV Andi Offset. Yogyakarta.

Nazir, Moh. 2005. Metode Penelitian. Penerbit Ghalia Indonesia.

Peraturan Direktur Jenderal Pajak Nomor: PER-16/PJ/2016 Tentang Pedoman TeknisTata Cara Pemotongan, Penyetoran Dan Pelaporan Pajak Penghasilan Pasal 21 Dan/Atau Pajak Penghasilan Pasal 26 Sehubungan Dengan Pekerjaan, Jasa, Dan Kegiatan Orang Pribadi.2016

Peraturan Menteri Keuangan Republik Indonesia Nomor 23/PMK.03/2020 tentang Insentif Pajak untuk Wajib Pajak Terdampak Wabah Virus Corona.

Peraturan Menteri Keuangan Republik Indonesia Nomor 44/PMK.03/2020 tentang Insentif Pajak untuk Wajib Pajak Terdampak Pandemi Corona Virus Disease 2019.

Peraturan Menteri Keuangan Republik Indonesia Nomor 86/PMK.03/2020 Tentang Insentif Pajak Untuk Wajib Pajak Terdampak Pandemi Corona Virus Disease 2019.

Peraturan Menteri Keuangan Republik Indonesia Nomor 110/PMK.03/2020 Tentang Perubahan Atas Peraturan Menteri Keuangan Nomor 86/PMK.03/2020 Tentang Insentif Pajak Untuk Wajib Pajak Terdampak Pandemi Corona Virus Disease 2019.

PPh Pasal 21 Diandalkan Menjadi Penggerak Penerimaan Pajak. 2020. https://insight.kontan.co.id.

Undang-Undang Republik Indonesia Nomor 28 Tahun 2007 Tentang Perubahan Ketiga Atas Undang-Undang Nomor 6 Tahun 1983 Tentang Ketentuan Umum Dan Tata Cara Perpajakan. 2007

Undang-Undang Republik Indonesia Nomor 36 Tahun 2008 Tentang Perubahan Keempat Atas Undang-Undang Nomor 7 Tahun 1983 Tentang Pajak Penghasilan. 2007

Waluyo. 2011. Perpajakan Indonesia. Edisi 10 Buku 1. Penerbit Salemba Empat. 
